Corinne Bigot and Catherine Lanone, eds., "With a Roar from Underground." Alice Munro's Dance of the Happy Shades

\title{
Claire Omhovère
}

\section{(2) OpenEdition}

\section{Journals}

Electronic version

URL: https://journals.openedition.org/ces/4683

DOI: $10.4000 /$ ces.4683

ISSN: 2534-6695

Publisher

SEPC (Société d'études des pays du Commonwealth)

\section{Printed version}

Date of publication: 1 April 2017

Number of pages: 123-124

ISSN: 2270-0633

\section{Electronic reference}

Claire Omhovère, "Corinne Bigot and Catherine Lanone, eds., "With a Roar from Underground." Alice Munro's Dance of the Happy Shades", Commonwealth Essays and Studies [Online], 39.2 | 2017, Online since 03 April 2021, connection on 04 June 2021. URL: http://journals.openedition.org/ces/4683 ; DOI: https://doi.org/10.4000/ces.4683

This text was automatically generated on 4 June 2021.

\section{$\circledast \oplus \Theta \Theta$}

Commonwealth Essays and Studies is licensed under a Licence Creative Commons Attribution - Pas d'Utilisation Commerciale - Pas de Modification 4.0 International. 


\title{
Corinne Bigot and Catherine Lanone, eds., "With a Roar from Underground." Alice Munro's Dance of the Happy Shades
}

\author{
Claire Omhovère
}

\section{REFERENCES}

Corinne Bigot and Catherine Lanone, eds. “With a Roar from Underground." Alice Munro's Dance of the Happy Shades. Collection Intercalaires: Agrégation d'anglais. Paris: PU de Paris Ouest, 2015. 190 p. ISBN: 978-2-84016-235-3. €12

1 Along with the incisive introduction that precedes them, the twelve essays gathered in this volume have reached the general public as the result of a conjunction of events. In 2014 and 2015, Alice Munro's Dance of the Happy Shades (1968) was part of the syllabus of the French Agrégation, the highly competitive exam that selects aspiring English teachers at the national level. Its inclusion no doubt reflected the surge of worldwide interest in Munro's writing after the Canadian writer was awarded the 2013 Nobel Prize for literature, and it also prompted a whole series of cultural events, talks and conferences in major French universities. The essays collected in the volume were thus presented in an oral form in the universities of Paris Ouest-Nanterre and of the Sorbonne-Nouvelle in the spring of 2015 by a group of European scholars who had been invited to Paris on that occasion. The interest of these essays, however, goes well beyond the immediate need to bring out to a new critical audience fresh reflections on Munro's first collection of stories. If the volume amply met this initial goal, it is now obvious that the essays it comprises also deserve to be brought to the attention of the international community of Munrovian scholars and, beyond them, anyone with an interest in the short story as an inexhaustible, shape-shifting form. 
2 The volume strikes a fine balance in its gathering essays devoted to individual stories from Dance of the Happy Shades along with more transversal approaches that relate Munro's first collection to her subsequent production. The essays also include readings of short stories that critics have tended to overlook, "Postcard" for instance, or that Munro herself has been known to reject, which may also have diverted critical attention from them, although their complex narrative setups deserve much more than passing interest. Such is the case with "The Time of Death" and "A Trip to the Coast," both of which are the objects of thorough textual analyses bringing out the exquisite craftsmanship that goes into creating the deceptive surface effects found in Munro's short stories, as evinced in Adrian Grafe's essay on "The Unreal Material." Readers familiar with the critical discourse surrounding Munro's writing will also find that many of the essays offer synthetic approaches on preoccupations ubiquitous in Munro's oeuvre, among which power games, class anxieties, social visibility and gender construction. Although these questions have admittedly been extensively researched, the textual dynamics that involve Munro's readers into questioning the values corseting a society that had little space for the characters' aspirations well deserve the consideration they receive in With a Roar from Underground. Four of the present essays start from Beverly Rasporitch's analysis of clothes in Dance of the Happy Shades and take the motif further to explore what clothing says about the female body, the affects it mediates and the symbolic relations it expresses. Enlightening use is made of Daniel Sibony's work on femininity and the function of clothing that simultaneously conceals and reveals the absence hollowing out women's relation to their own body. In this respect Sabrina Francesconi's socio-semiotic study of "Red Dress-1946" is extremely fruitful in demonstrating that Munro's language works expressively far more than descriptively.

3 Wielding the magnifying glass of close reading, the contributors to this volume reveal the full extent of recurring themes and techniques, as well as Munro's highly idiosyncratic ways with language. Revision aptly describes the stance most of them adopt regarding Munro's early stories, and I would concur with Ailsa Cox when she argues that revision needs to be understood in relation to an entire oeuvre haunted by the possibilities of failure and ostracism: "This idea, that the story is always open to revision, informs [Munro's] aesthetic, both technically and philosophically" (56). Revision does yield invaluable insights when it comes to Héliane Ventura's analysis of the palimpsestic structure and intertextual ramifications of "Postcard," or Vanessa Guignery's meticulous analysis of voice construction and narrative polyphony. The infraordinary, a term Lynn Blin borrowed from Georges Perec's Species of Spaces, opens new perspectives on the background noise of social exchanges Munro excels at rendering, along with the banality of her characters' lives and their stubborn sometimes silent, sometimes strident - rebellions. Although Kathie Birat does not call upon the notion of the infraordinary, the attraction it exerts upon Munro's writing is everywhere perceptible in Birat's study of doxographic language in "Thanks for the Ride," where clichés and stereotypes saturate discourse and deprive the speaking subject from her embodied enunciation. The two essays devoted to "The Shining Houses" - another story which Munro, of her own admission, did not regard as too successful - should help readers go beyond the fallacy of authorial intentions and consider how reception liberates the creative potential of texts. This aspect is most striking in Thomas Dutoit's Derridean reading of the latter story and the unsuspected tensions it discloses between "the materiality of the earth and the formality of the 
world" (146), an uneasy coexistence Munro has not ceased to explore in the rest of her writing.

All in all, this new volume about Munro's perhaps best-known collection of stories has a wonderfully cumulative appeal about it. It bears witness to the vitality of the transcontinental exchanges that have contributed so much to recent evolutions in Munrovian criticism. To it, it adds a much needed text-oriented approach that reveals original aspects in Munro's handling of language, particularly her deft use of ungrammaticality and the unsaid. Finally, the volume contains a thoughtfully selected bibliography (177-86), which makes it a useful, compact guide for any student seeking directions in the thriving field of Munrovian criticism, but also for the many readers among us who will never tire of learning more about stories that have become life-time companions.

\section{AUTHORS}

\section{CLAIRE OMHOVÈRE}

Claire OMHоvÈRE teaches English and Commonwealth Literature at University Paul Valéry Montpellier 3 (France) where she is affiliated to the research group EMMA (Etudes

Montpellieraines du Monde Anglophone). Her research is broadly concerned with perceptions and representations of space in postcolonial literatures with a specific interest in the aesthetic and ethical dimensions of landscape writing in settler-invader colonies such as Canada, Australia and New Zealand. The author of many articles, her books include Sensing Space: The Poetics of Geography in Contemporary English-Canadian Fiction (Peter Lang, 2007) and the edited collection L'Art du paysage (Michel Houdiard, 2014). 